\title{
Paryskie ślady przyrodniczych badań Kaukazu Ludwika Młokosiewicza (183I-1909)
}

\section{Paris traces of Ludwik Młokosiewicz}

Ludwik Młokosiewicz was a collaborator of the Zoological Cabinet of Warsaw and an explorer of the Caucasian nature. The Caucasian specimens he collected can be found in several naturalist collections all over Europe. The author undertook the research of Młokosiewicz's traces in Paris for two reasons: firstly, because of the relationship between the National Museum of Natural History (MNHN) and the Zoological Cabinet of Warsaw; secondly, because of Ludwik Młokosiewicz's visit in Paris in 1875. Besides the specimens in the collection of the MNHN (which include the holotype of the Caucasian salamander), the author found only one letter from Ludwik Młokosiewicz to Jerzy Wandalin Mniszech. The subject of this letter is the trade of beetles and the project of an expedition to Georgia and Armenia.

Keywords: Ludwik Młokosiewicz, fauna of Caucase, Paris' natural history collections Słowa kluczowe: Ludwik Młokosiewicz, fauna Kaukazu, paryskie kolekcje przyrodnicze

Życie i praca naukowa Ludwika Młokosiewicza są stosunkowo dobrze poznane. Uczony ten doczekał się kilku publikacji biograficznych1. Zważywszy na znaczenie ówczesnej stolicy Francji dla polskich przyrodników związanych z Warszawskim Gabinetem Zoologicznym, autorowi wydawało się interesującym sprawdzenie, czy w tym mieście zachowały się jakieś ewentualne ślady działalności Młokosiewicza. To głównie we francuskich pismach Władysław Taczanowski i Antoni Waga opisywali nadsyłane przez Młokosiewicza okazy

1 B. Hryniewiecki, Ludwik Młokosiewicz - miłośnik i badacz przyrody Kaukazu (1831-1909), „Wszechświat” 1950, s. 136-139; A. Chodubski, Ludwik Młokosiewicz (1831-1909) - pionier badań flory i fauny Kaukazu, „Kwartalnik Historii Nauki i Techniki” t. 27, 1982, nr 2, s. 421-428; W. Gil, Ludwik Młokosiewicz - polski badacz na Kaukazie, „Sylwan” 2013, s. 158-160. 
i publikowali informacje o faunie Kaukazu. Właśnie w „Revue et Magasin de Zoologie Pure et Appliquée", piśmie utworzonym przez korespondenta i przyjaciela polskich przyrodników Félixa Édouarda Guérin-Méneville'a (1799-1874), Waga opisał, nowy nieznany gatunek salamandry² z Kaukazu, a opis rozpoczął słowami:

Zwierzę, którego przedstawiam opis, jest znane jedynie z dwóch okazów znalezionych przez Pana Młokosiewicza w regionie najwyższych wzniesień Kaukazu, ponad granicą lasu, w strefie traw. Szczególnie jeden z okazów jest godny uwagi z racji obecności sześciu palców na tylnych kończynach, podczas gdy drugi ma tylko pięć. Pierwszy oddaję paryskiemu Jardin des Plantes, a drugi warszawskiemu Muzeum Zoologicznemu³.

W 1875 r. Młokosiewicz odwiedził Paryż. Odebrał wtedy od Konstantego Branickiego pieniądze za przesyłane z Kaukazu okazy. Taczanowski, dość surowo w swoich listach oceniający przyrodnika z Kaukazu, pisał 5 lutego 1876 r. na temat tej wizyty4:

Ciekawym bardzo, jakie wrażenie zrobił Młokosiewicz. Jest to oryginał jakich mało, przedstawiający rozmaite kontrasty, z jednej strony dobre chęci, z drugiej niedołęstwo. Tak np. wzięte w Paryżu pieniądze użył na zakup narzędzi preparatorskich. Naprawdę zaś potrzebny mu nóż ze scyzorykiem i ze dwie pary pęset. Inne narzędzia nie wpłyną na jakość ani ilość zbiorów ${ }^{5}$.

W 1868 r., po powrocie na Kaukaz z przymusowego osiedlenia, gdzie przebywał jako podejrzany o udział w „polskim spisku” i chęć wywołania antyrosyjskiego powstania ludów Kaukazu, Młokosiewicz nawiązał współpracę z Wagą. Przesyłał okazy fauny kaukaskiej zarówno do Warszawskiego Gabinetu Zoologicznego, jak i do prywatnej kolekcji Wagi ${ }^{6}$. To także za pośrednictwem tego uczonego sprzedawał okazy owadów z Kauka-

2 Mertensiella caucasica (Waga, 1876); Antoni Waga opisał gatunek pod nazwą Exaeretus Caucasicus.

3 A. Waga, Nouvelle espèce de Salamandride, "Revue et Magasin de Zoologie Pure et Appliquée” seria 3, t. 4, 1876, s. 326-328 (tłumaczenie P.D.).

4 K. Kowalska, A. Mroczkowska, B. Zielińska, Władysław Taczanowski. Listy do Antoniego Wagi, Konstantego Branickiego i Benedykta Dybowskiego, Wrocław-Warszawa-Kraków 1964 („Memorabilia Zoologica”, t. 12), s. 129.

5 Taczanowski bardzo surowo oceniał umiejętności preparatorskie i zmysł organizacyjny Młokosiewicza. W liście do Wagi z 28 III 1877 r. pisał np.: „Młokosiewicz bardzo nędzny zbieracz, pisał on, że z bytności Ignaca [Ignacego Wesołowskiego] bo się nauczył dobrze skóry urządzać. Wcale tego nie widać, skóry ostatniego jego transportu wcale nie lepsze, taka tylko różnica, że kij się w środku znajduje. Stosunek z nim przynosi więcej przykrości niż pożytku, bo się spodziewa dobrego przychodu, a tymczasem tak złe skóry przysyła, że wiele z nich trzeba na śmiecie wyrzucić. Tymczasem, jak się pokazuje, fauna kaukaska bardzo niedostatecznie znana. W ostatnich czasach przysłał on sowę bardzo ciekawą, ale w skórze bardzo źle zrobionej" (K. Kowalska, A. Mroczkowska, B. Zielińska, op. cit., s. 132.). Z perspektywy czasu można zauważyć, że uwagi Taczanowskiego były bardzo krzywdzące. Wiele z nadsyłanych przez Młokosiewicza okazów po dzień dzisiejszy przechowywanych jest w europejskich kolekcjach zoologicznych. W korespondencji Taczanowskiego zawartych jest wiele informacji jak np. ta: „Młokosiewicz wyprawił z Kaukazu nową posyłkę, w której oprócz innych rzeczy mają być trzy skóry z tamtejszych muflonów, antylopa skalna, kot czarny i kilka innych ssących" (K. Kowalska, A. Mroczkowska, B. Zielińska, op. cit. s. 120). Sam Taczanowski wielokrotnie wykorzystywał je w swoich pracach, nie ograniczając się przecież do cietrzewia kaukaskiego (patrz np. L. Taczanowski, Contributions à la Faune Ornithologique du Caucase, „Bulletin de la Société Zoologique de France” t. 12, 1887, s. 618-626).

6 Waga kupował do swoich zbiorów część okazów przesyłanych przez Młokosiewicza. W liście z 28 III 1877 r. Taczanowski informował Wagę: „Owe 50 rubli wręczyłem Dębowskiemu, a ten je zaraz odesłał Młokosiewiczowi wraz z innymi jego funduszami. Czy mu wymienił w liście, że te pieniądze są od Pana Profesora, tego Dębowski nie pamięta. W każdym razie je odebrał, a zaś w listach jest nieporządny i często zaniedbuje donosić o interesach pieniężnych" (K. Kowalska, A. Mroczkowska, B. Zielińska, op. cit. s. 133). Waga pomagał także w przesyłaniu Młokosiewiczowi pieniędzy przez francuskich handlarzy okazami przyrodniczymi. 
zu francuskim entomologom. Ślady tej współpracy odnaleźć można nie tylko w różnych europejskich kolekcjach entomologicznych, lecz także we współczesnym nazewnictwie zoologicznym. Victor Antoine Signoret (1816-1889) zadedykował polskiemu badaczowi Kaukazu nowoopisany gatunek pluskwiaka Hyalesthes mlokosiewiczi, a w 1880 r. Jacques Marie Frangile Bigot (1818-1893) - nowy dla nauki gatunek z rodziny bąkowatych Chrysops mlokosiewiczi.

Taczanowski w liście do Wagi z 2 czerwca 1870 pisał:

Dzisiaj otrzymałem list od Młokosiewicza z Kaukazu, donosi, iż posiada piękną skórę kozła dzikiego i pewną liczbę ptaków, ale wątpię, aby te ostatnie były dobrze urządzone, prawi mi o mnogości gadów w tamtej okolicy, o dwusążniowych wężach, ale z tymi dla niego niełatwa sprawa, bo nie ma funduszów odpowiednich na należyte ich upakowanie, ani dość doświadczenia. Owady mogą być najlepsze, bo to najmniej zachodu wymaga ${ }^{7}$.

Nie wiadomo czy zbieranie owadów rozpoczął Młokosiewicz w rezultacie sugestii Taczanowskiego, czy wynikało ono z jego własnych zainteresowań, czy też życzeń współpracujących z nim entomologów z instytucji rosyjskich, np. Oktawiusza Radoszkowskiego (1820-1895), czy też po prostu to właśnie owady były najłatwiej i najlepiej sprzedającym się „towarem” na europejskim rynku okazów przyrodniczych. Zajęcie się łowieniem owadów było niewątpliwie bardzo szczęśliwą decyzją. Okazy złowione przez Młokosiewicza odegrały ważną rolę dla poznania entomofauny Kaukazu.

Przeprowadzone przez autora w Paryżu poszukiwania doprowadziły do odnalezienia listu, który Młokosiewicz przesłał Jerzemu Mniszchowi (1824-1881). List przechowywany jest w Instytucie Francuskim (Institut de France) ${ }^{8}$ wraz z licznymi dokumentami związanymi z tym polskim arystokratą, panią Hańską (która była jego teściową) i Balzakiem. Mniszech, pasjonat entomologii, zgromadził jedną z największych na świecie kolekcji chrząszczy ${ }^{9}$.

Treść listu jest następująca:

Łagodechi, 18 12/II 75

\section{Szanowny Panie Hrabio,}

List Pana Hrabiego i 100 rubli wkrótce otrzymałem po Nowym Roku. Jak prędkiem wysłaniem pieniędzy, tak i cena, oszacowana amatorami, za owady ja zupełnie zadowolony, mało tego, Pan Hrabia zaokrąglił summę do 100 rubli: Mój obowiązek teraz doprowadzać takiem sposobem czem mogę, to jest interesować Jego mojemi zbiorami jak najwięcej, dla czego postaram się je urozmaicić o ile możności. Użyję wszelkie środki aby podróż moja do Armenji, Abbaz-Tumanu, Imeretji przyszła do skutku, gdzie spodziewam się na bogate zbiory, i otrzymać gatunki, mniej więcej,

7 K. Kowalska, A. Mroczkowska, B. Zielińska, op. cit., s. 111-112.

8 Instiut de France, zespół Lettres autographes adressées au comte et à la comtesse Georges Mniszech, gendre et fille de $M^{\text {me }}$ de Balzac, sygn. Ms Lov. A 383 bis.

9 P. Daszkiewicz, Paryska sprzedaż entomologicznej kolekcji Jerzego Wandalina Mniszcha (1824-1881) - jedno z najważniejszych wydarzeń dziewiętnastowiecznej zoologii, „Kwartalnik Historii Nauki i Techniki” t. 58, 2013 nr 4, s. 61-70. 
które Pan Hrabia życzył by sobie mieć. W tej przyjemnej nadzieji pozostaje Pana Hrabiego z prawdziwym szacunkiem życzliwym sługą.

Ludwik Młokosiewicz

List ten jest interesującym przyczynkiem dla historii dziewiętnastowiecznej zoologii. Z jednej strony stanowi on świadectwo nieznanej dotychczas współpracy obu przyrodników. Możemy jedynie przypuszczać, że Młokosiewicz poznał Mniszcha dzięki Wadze, Branickiemu lub Taczanowskiemu. Możemy również przypuszczać, że obaj przyrodnicy spotkali się podczas wizyty Młokosiewicza w Paryżu. Znajmość z Mniszchem, jednym z najbardziej znanych i najzamożniejszych w Europie kolekcjonerów chrząszczy, zapewne otwierała przed przyrodnikiem z Kaukazu nowe perspektywy sprzedaży łowionych okazów. Sto rubli było pokaźną kwotą zważywszy, że za 1000 można było kupić w Kongresówce niewielkie gospodarstwo, a dniówka robotnika wynosiła w Warszawie około 60 kopiejek. Materialna strona funkcjonowania kolekcji przyrodniczych w XIX w. jest nadal słabo poznana choć historycy nauki zwracają uwagę na znaczenie prywatnych kolekcji i rynku o okazów dla rozwoju dziewiętnastowiecznej entomologiii ${ }^{10}$. Także $z$ tego punktu widzenia list ten jest źródłem interesującej informacji. List przechowywany w Instytucie Francuskim jest jedynym znanym. Zapewne korespondencja ta była obszerniejsza i być może dalsze poszukiwania w archiwach dostarczą nowych dokumentów na temat związków Młokosiewicza z Mniszchem.

\section{Bibliografia}

Chodubski A., Ludwik Młokosiewicz (1831-1909) - pionier badań flory i fauny Kaukazu, „Kwartalnik Historii Nauki i Techniki” t. 27, 1982, nr 2, s. 421-428.

Daszkiewicz P., Paryska sprzedaż entomologicznej kolekcji Jerzego Wandalina Mniszcha (1824-1881) - jedno z najważniejszych wydarzeń dziewiętnastowiecznej zoologii, „Kwartalnik Historii Nauki i Techniki” t. 58, 2013 nr 4, s. 61-70.

Gil W., Ludwik Młokosiewicz- Polski badacz na Kaukazie, „Sylwan” 2013, s. 158-160.

Hryniewiecki B., Ludwik Młokosiewicz - miłośnik i badacz przyrody Kaukazu (1831-1909), „Wszechświat” 1950, s. 136-139.

Kowalska K., Mroczkowska A., Zielińska B., Władysław Taczanowski Listy do Antoniego Wagi Konstantego Branickiego i Benedykta Dybowskiego, Wrocław-Warszawa-Kraków 1964 („Memorabilia Zoologica”, t. 12).

Moret P., Entomologistes et chasszeurs d'insectes en Amérique du Sud au XIXe siècle, [w:] $118^{\mathrm{e}}$ Congrès national des sociétés historiques et scientifiques, Section d'histoire des sciences, CTHS, Pau 1993, s. 395-408

Taczanowski L., Contributions à la Faune Ornithologique du Caucase, „Bulletin de la Société Zoologique de France" t. 12, 1887, s. 618-626.

Waga A., Nouvelle espèce de Salamandride, „Revue et Magasin de Zoologie Pure et Appliquée" seria 3, t. 4, 1876, s. 326-328.

10 P. Moret, Entomologistes et chasszeurs d'insectes en Amérique du Sud au XIXe siècle, [w:] $118^{e}$ Congrès national des sociétés historiques et scientifiques, Section d'histoire des sciences, CTHS, Pau 1993, s. 395-408. 
dr hab. Piotr Daszkiewicz, prof. PAN, jest przyrodnikiem i historykiem nauki, doktorem nauk biologicznych, doktorem habilitowanym nauk humanistycznych, profesorem w Instytucie Historii Nauki im. L. i A. Birkenmajerów PAN PAN w Warszawie, pracownikiem Agence Française pour la Biodiversité, wieloletnim pracownikiem Narodowego Muzeum Historii Naturalnej w Paryżu i współpracownikiem paryskiej „Kultury” i Instytutu Literackiego w Maisons-Laffitte. Interesuje się historią nauk przyrodniczych, historią poznawania Puszczy Białowieskiej i badań nad żubrem, historią kolekcji i muzeografii przyrodniczej oraz historią polsko-francuskiej współpracy naukowej.

e-mail: piotrdas@yahoo.fr

Data zgłoszenia artykułu: 27 listopada 2018

Data przyjęcia do druku: 30 grudnia 2018 